\title{
INCIDENCE OF MEDICAL COMPLICATIONS IN SPINAL CORD INJURY: PATIENTS IN SPECIALISED, COMPARED WITH NON-SPECIALISED CENTRES
}

\author{
By William H. Donovan, M.D., ${ }^{1}$ R. Edward Carter, M.D., ${ }^{1}$ Sir George \\ M. BEDBROOK, F.R.A.C.S., ${ }^{2}$ JoHN S. YounG, M.D., ${ }^{3}$ and Ellis R. \\ GRIFFITHS, F.R.A.C.S. ${ }^{2}$. \\ ${ }^{1}{ }_{1} 333$ Moursund, Houston, TX77030 U.S.A. ${ }^{2}$ Royal Perth Rehabilitation Hospital, \\ Selby Street, Shenton Park, Western Australia 60o8. ${ }^{3}$ National Spinal Cord Injury \\ Data Research Centre, I I 30 E. McDowell Road, Suite A-6, Phoenix, AZ 75006, U.S.A.
}

Summary. Facilities providing a co-ordinated 'system' of care to the spinal cord injured are now more accepted as being preferable to fragmented 'non-system' facilities. Data reflecting the incidence of selected complications common to spinal cord injury were collected over a 2-year period from a system located outside the United States and from 'non-systems' within the United States. The latter was defined as care provided in community facilities prior to entry into one of 14 model United States spinal cord injury centres.

All complications occurred more frequently in the American group, particularly decubitus ulcers and urinary tract infections.

The data suggest that system care is preferable to non-system care in its capacity to prevent costly complications and the sooner the spinal cord injured patient is referred to a spinal cord centre capable of meeting all his needs, the less likely will he be exposed to complications that could slow the rehabilitation effort.

Key words: Spinal cord injury; Medical complications; Systems of care; Early care; Comprehensive care.

\section{Introduction}

THE NEED for comprehensive care for the individual with spinal cord injury has become generally accepted over the past 20 years (Guttmann, 1976). Throughout the world, efforts have centred on the development of a system which incorporates a smooth, co-ordinated transition throughout all the phases of treatment that the patient requires.

In contrast with other countries such as Australia, where the spinal cord injured are usually managed by the same doctor from injury to demise, United States systems of care have in the past been characterised by a fragmentation marked by an abrupt change which occurred at a time when acute care was concluded and rehabilitation begun. As part of the effort to foster the improvement of care to the spinal cord injured, the Model Systems Programme (funded by the Rehabilitation Services Administration, Department of Health and Human Services and which includes seventeen spinal cord centres throughout the United States), has set the development of close and integrated ties between acute and rehabilitation care providers as one of its major priorities (Federal Register, I979).

The exact definition of what actually constitutes a true system, or standard to which all seventeen centres in the U.S. might conform, has not yet been agreed upon by all. Thus, it is not surprising that a prior analysis 
of variance of parameters of care provided within the American model centres, presented at the I98I scientific session of The American Spinal Injury Association, indicated that it was the differences among Centres, and how they operate, which accounted for most of the variance related to time of entry and length of stay.

In the face of such difficulty it would seem that an ideal system must be defined. Most authorities in the U.S. now agree such a system should admit every victim of spinal cord trauma in its catchment area within 24 to 48 hours, regardless of the presence of other medical problems, additional trauma, financial constraints or social class differences. It should also provide for all phases of care under a single roof, or within a defined system, and should concentrate the staff expertise, facilities and equipment in one area in order to promote optimum patient care and cost effectiveness. With such a system it should be possible to know what value the system is to the entire community (American Spinal Injury Association; I98I).

Since none of the U.S. model systems during the period of this study could conform to these criteria, the authors chose the spinal cord centre in Perth, Western Australia as the standard since most of the conditions described above already exist (Bedbrook 1979).

Against this system it was decided to compare non-specialised systems in the U.S. relative to the incidence of selected complications known to occur during the acute phase of spinal cord injury. Two questions were then posed: a) Do complications occur even in such a system as described and with what,frequency; and b) what was the frequency of the same complications reported by the U.S. model systems occurring before patients came within their ambit? Data obtained at the time a patient entered every U.S. model system (which concerned complications that occurred before such entry), were regarded as a reflection of care provided in a non-system. Many of the complications selected are known to be preventable when the patient is initially cared for in an environment that contains the staff, facilities and expertise necessary for their prevention. Non-systems, such as community hospitals with no affiliation to a spinal cord injury centre, are likely to see too few such injuries annually to make the securing of such staff and facilities cost-effective since the incidence of the condition lies between three to five per 100,000 population per year.

\section{Materials and Methods}

Cases of spinal cord injury were analysed from two sources.

I. The I IO patients admitted to the spinal cord unit at the Royal Perth Rehabilitation Hospital in Perth, Western Australia during the years 1979 and 1980 included all individuals who sustained an injury to the spinal cord, regardless of its degree of completeness, as well as many of those who sustained spinal trauma without neurological deficit, throughout the entire state of Western Australia, an area which covers approximately one third of the continent of Australia (Table I). Excluded were only those individuals who died within the first 48 hours of injury and two patients who expired during the first sixty days post trauma.

2. Sixteen hundred and six patients admitted to one of the 14 model centres existing during the years 1979 and I980 were subdivided into four groups based upon whether they were admitted into the spinal cord injury 
TABLE I

The number and per cent of patients admitted to the spinal cord injury unit in Perth, Australia during the time since injury shown, I979-I980.

\begin{tabular}{lrr}
\hline \multicolumn{1}{c}{ Time since injury } & N & $\%$ \\
\hline Less than 24 hours & IO5 & 9 I \\
Between 24-48 hours & 5 & 4 \\
Sub-Total & I 0 & 95 \\
Greater than 48 hours & 6 & 5 \\
Total & I 6 & 100 \\
\hline
\end{tabular}

\section{TABLE II}

The number and per cent of patients in four categories of neurological deficit viz. tetraplegia and paraplegia, complete and incomplete. Those patients who showed no or transient neurological loss are labelled as 'no deficit', I979-1980.

\begin{tabular}{lrr}
\hline & N & \multicolumn{1}{c}{$\%$} \\
\hline Tetraplegia incomplete & 3 I & 28 \\
Tetraplegia complete & I & I5 \\
Paraplegia incomplete & I3 & I2 \\
Paraplegia complete & 5 & 5 \\
Sub-Total & 66 & 60 \\
No Deficit & 44 & 40 \\
Total & I I0 & I00 \\
\hline
\end{tabular}

unit rehabilitation hospital itself or its affiliated trauma centres within the first, second, third or fourth 2-week period following injury.

Both groups were then analysed for complications. The records of all 66 patients in Perth with neurological deficits, and the information reported to The National Spinal Cord Injury Data Research Center in Phoenix, U.S.A. on all sixteen hundred and six patients in the U.S.A., were studied relative to the incidence of seven selected medical complications. The complications were then counted for all patients entering within each time frame. Since all patients in Perth were admitted within 48 hours (Table II), these same 66 patients were studied over each time frame and the occurrence of each complication, if any, was recorded. It was hoped that the minimal expectation of each complication in a system could be asertained. Among the American patients each time frame represented a separate group; the occurrence of complications before each patient entered the ambit of the model centres were retrieved from Phoenix, via the data forms which were completed at the time each patient was admitted to a model centre, and forwarded on to the National Spinal Cord Injury Data Research Center.

\section{Results}

The occurrence of the seven selected complications occurring in both the 66 Australian patients and each group of the American patients over each 
TABLE III

The frequency of seven complications to which patients with spinal cord injury are vulnerable are shown. The four time frames are the periods of observation when these complications may have occurred on all 66 patients in Perth who entered the unit within 48 hours.

\begin{tabular}{lcccc}
\hline \multicolumn{1}{c}{ Days } & I-I5 & I6-30 & 3I-45 & $46-60$ \\
\hline & $\mathrm{N}$ & $\mathrm{N}$ & $\mathrm{N}$ & $\mathrm{N}$ \\
U.T.I. & 5 & 3 & 6 & 4 \\
Decub. Ulcer & 0 & 0 & 0 & 0 \\
Atelectasis & 4 & 0 & 0 & 0 \\
Pneumonia & 2 & 0 & $\mathrm{I}$ & 0 \\
Pul. Embolus & $\mathrm{I}$ & 2 & 0 & 0 \\
G.I. Ulcer & 0 & 0 & 0 & 0 \\
Heterotopic Ossification & $\mathrm{O}$ & $\mathrm{O}$ & $\mathrm{0}$ & 0 \\
\hline
\end{tabular}

TABLE IV

The frequency of seven complications to which patients with spinal cord injury are vulnerable are shown. The four time frames are the periods of observation when these complications were recorded as the patients entered the U.S.A. spinal cord injury units. Each group was comprised of different patients whose complications occurred before they were admitted.

\begin{tabular}{|c|c|c|c|c|c|c|c|c|}
\hline Days & \multicolumn{2}{|c|}{ I-I 5} & \multicolumn{2}{|c|}{$16-30$} & \multicolumn{2}{|c|}{$3 I-45$} & \multicolumn{2}{|c|}{$46-60$} \\
\hline Model System & \multirow{2}{*}{\multicolumn{2}{|c|}{840}} & \multirow{2}{*}{\multicolumn{2}{|c|}{342}} & \multirow{2}{*}{\multicolumn{2}{|c|}{260}} & \multirow{2}{*}{\multicolumn{2}{|c|}{ I64 }} \\
\hline Grand Total & & & & & & & & \\
\hline & $\mathbf{N}$ & $\%$ & $\mathbf{N}^{-}$ & $\%$ & $\mathbf{N}$ & $\%$ & $\mathbf{N}$ & $\%$ \\
\hline U.T.I. & 24 & $2 \cdot 9$ & 99 & $28 \cdot 9$ & 100 & $38 \cdot 5$ & 82 & $50 \cdot 0$ \\
\hline Decub. Ulcer & 13 & $\mathrm{I} \cdot 5$ & 59 & $17 \cdot 3$ & 65 & 25.0 & 58 & $35 \cdot 4$ \\
\hline Atelectasis & 21 & $2 \cdot 5$ & 42 & $12 \cdot 3$ & 40 & 15.4 & 29 & $17 \cdot 7$ \\
\hline Pneumonia & I6 & I.9 & 43 & $12 \cdot 6$ & 30 & I I 5 & 20 & $12 \cdot 2$ \\
\hline Pul. Embolus & 0 & 0 & 5 & I. 5 & 9 & $3 \cdot 5$ & 8 & 4.9 \\
\hline G.I. Ulcer & I & $0 \cdot I$ & 6 & $I \cdot 8$ & 9 & $3 \cdot 5$ & 6 & $3 \cdot 7$ \\
\hline Heterotopic Ossification & 0 & 0 & 0 & 0 & I & 0.4 & 0 & 0 \\
\hline
\end{tabular}

I5-day time frame is shown in Tables III and IV. In addition (for further comparison), the incidence of these same complications occurring in 1,615 patients admitted into the model centre systems themselves during the first 24 hours is shown in Table V. However, the available data in Table V could not be broken down into I5-day time frames and the period of observation for these patients extends beyond 8 (weeks and covers the entire hospitalisation prior to the first definitive discharge (Young et al., 1982).

\section{Discussion}

The Spinal Cord Unit in Perth, Western Australia, was chosen as a standard for comparison for a number of reasons. It has been in operation since 1954 and over the years has acquired a reputation for excellence in all phases 
TABLE V

The frequency of seven complications to which patients with spinal cord injury are vulnerable are shown. These complications occurred in patients who were admitted to U.S.A. spinal units within 24 hours. The period of observation could not be broken down into 42 -week time frames as in Tables III and IV. Instead it represents the entire initial hospitalisation. $(\mathrm{N}=1615)$.

\begin{tabular}{lrr}
\hline Complication & \multicolumn{1}{c}{ N } & \multicolumn{1}{c}{$\%$} \\
\hline U.T.I. & rog6 & 67.9 \\
Decub. Ulcer & 376 & 23.3 \\
Atelectasis & 233 & 14.4 \\
Pneumonia & 227 & $14 . I$ \\
Pul. Embolus & 74 & 4.6 \\
G.I. Ulcer & 7 & 0.4 \\
Heterotopic Ossification & 12 & 0.7 \\
\hline
\end{tabular}

of care for the spinal cord injured person (Bedbrook 1979). In essence, the principles espoused by the late Sir Ludwig Guttmann have been applied and a system of rescue, retrieval, acute care, rehabilitation and follow-up has been well established and its efficacy demonstrated, yielding enviable results. This ability to offer a severely injured person a smooth pathway towards return to maximum function within society with minimal complications arose from the uniform application of standards of care and quality control. This in turn was made possible by the concentration of experienced staff, equipment and facilities in a spinal cord unit.

Without such concentration of patients with similar clinical problems provision of the necessary staff and facilities loses cost effectiveness. The purpose of this study was not however, intended to prove statistically that the 'system' concept of care is more cost effective, though we believe it is. Rather it was to show that costly complications can be prevented by an adequate amount of knowledgeable staff and appropriate facilities and equipment. We have also shown that these complications are very likely to occur in a 'non-system' and even in a 'system' where full control of the patient by the experienced staff may not begin soon enough.

\section{Urinary Infection}

Urinary tract infections (UTI) are known to occur commonly in patients with neuropathic bladders. The use of intermittent catherisation during early management has contributed towards the ability to maintain sterile urine both by eliminating ready access to the bladder by bacteria along the side of an indwelling catheter and by providing a rationale for the use of antibiotics in the treatment of bacteriuria. However, when applied incorrectly, overdistention of the bladder or urethral trauma may occur. At the Perth Unit every effort is made to maintain a sterile urine. This includes rigid application of the principles of infection control, use of a sterile non-touch technique for catheter insertion and antibiotic treatment of all significant bacteriuria, whether or not fever is present (Pearman et al., I973). The data from Perth therefore reflect the incidence of significant bacteriuria 
(greater than 100,000 colonies), and indicate that despite all precautions bacteria can still gain access to the bladder, the risk remaining relatively constant between 5 and Io per cent (Table III). Prompt treatment of such bacteriuria ensures only infrequent sepsis or pyelonephritis with their attendant costly courses of intravenous antibiotics, not to mention the interferance with adequate nutritional intake and the patient's activity programme that such episodes may cause.

In contrast, the data from the U.S.A. show an increasing frequency of urinary tract infections the longer the patient remains in a hospital where the special conditions mentioned above are lacking (Table IV). No absolute comparison between the Perth and U.S.A. data can be made however, since the U.S.A. figures reflect both symptomatic and asymptomatic bacteriuria. If anything, bacteriuria is under-reported since it is common practice not to obtain a urine culture until the patient becomes febrile or develops obvious pyuria. If the incidence of colonisation of the urine (similar to the Perth figures), could have been obtained it is conceivable that they would have approached roo per cent in non-system hospitals.

\section{Decubitus ulcers}

The comparison of the incidence of decubitus ulcers is probably more valid since it is an entity easily recognised and defined. The Perth data show that in the correct environment it does not occur (Table III). The U.S.A. data prove how easily it occurs in the wrong environment, and how more likely it is to develop the longer the patient remains in a hospital where a full compliment of nursing staff who can recognise the early warning signs of pressure necrosis and take preventive action is not available (Table IV). Of all the preventable complications, to which the spinal cord injured patient is vulnerable, this is the costliest. If a pressure sore severe enough to require even one plastic surgical procedure develops it increases the total cost of that patient's care fivefold (Young et al., I982).

\section{Respiratory complications}

The respiratory parameters from Perth considered collectively confirm the vulnerability of the tetraplegic and high paraplegic patient during the early post-injury period, due to their inability to cough effectively and expectorate secretions, particularly if they have a history of heavy smoking, intrinsic lung disease, or have been given a general anaesthetic. Trained respiratory or physical therapists who can assist the patient to cough effectively round the clock and combat the tendency towards atelectasis, as well as personnel who can intubate, provide ventilator assistance and manage the respiratory pathophysiology are available in Perth. This may account in part for the relatively low incidence in that population as well as its containment to the first two weeks after injury (Table III). The incidence of atelectasis and pneumonia in the U.S.A. population entering the model systems beyond two weeks is roughly two to four times compared with that seen in the Perth population during the first week (Table IV). The U.S.A. and Perth figures may indicate that between five and twenty per cent of all patients are at risk for significant respiratory complications some time after the injury, but this risk may be minimised by proper treatment. While this may well justify 
the need for the special staff and equipment mentioned above on a cost effective basis, in some cases prevention will not be possible and vigorous corrective measures including intubation and tracheostomy will be required.

No definitive comment regarding pulmonary embolus is offered as the numbers are probably not significantly different. This may be a complication in which environment plays a smaller role.

\section{Peptic ulceration}

Gastric and duodenal ulceration was not reported in the Perth series (Table III). The incidence in the U.S.A. population is small but this can be a difficult problem to manage, particularly if abdominal surgery is required (Table IV) (Osteen et al., I98I). In the authors' experience restoration of normal alimentation and nutrition may require far more time than in the neurologically intact patient. The data suggest that this complication is preventable in the proper environment but the precise reason for this may require further investigation. Steroids such as dexamethasone have never been used for patients with traumatic spinal cord injury in Perth.

\section{Heterotopic ossification}

Heterotopic ossification was not reported in the Perth group and is also rare during the first 2 months post-injury in the United States series.

\section{Discussion}

The authors draw no specific inferences from the data in Table $\mathrm{V}$ since it is not comparable with respect to time frames. However, it is noteworthy that the information pertaining to patients entering the model centre systems within twenty-four hours regarding atelectasis, pneumonia and G.I. ulcers is similar to the non-system groups. Decubitus ulcers, as shown, do occur in our model systems. This may indicate remaining internal inadequencies or lack of sufficient control over what happens during the acute period within those hospitals included as part of each or some model centre systems.

Comparisons made between the Perth and U.S.A. data must be interpreted within the limitations that apply to all retrospective studies. The authors know from their own experience that complication rates in some U.S.A. spinal cord centres approximate those in Perth. In addition, the U.S.A. data do not reveal the magnitude of the bias caused by the failure to admit many of the minimally involved patients as well as those severely injured individuals who were not referred to a model centre until well after 60 days. The intention here is not to compare one national health care system against another but rather to compare a system's incidence of selected complications with those of non-systems. From these data we draw no statistical tests of validity since too many factors are uncontrolled in a retrospective study such as this. Our purpose is to point out that from a large series of cases we can say that problems with the care of spinal cord injured patients in the United States continue to exist and that some of the complications seen can be prevented.

Despite the selection of a hospital outside the U.S.A. as the standard the comparison presented seems valid since the cultures, systems of 
government and organised health care of Australia and America are similar. Admittedly, the capability to structure a system such as this in Perth is more easily achieved than in the somewhat more socialised system of medical care in Australia. Nevertheless, the data presented here provide support for the efforts already underway to bring the 'system concept' to spinal cord injury similar to what is currently available to burn victims in the U.S.A. In addition to all the medical, social and psychological benefits that accrue to the patient in a location prepared to meet all of his or her needs costly complications can be prevented, ensuring a healthier individual who can participate in a rehabilitation programme.

\section{Acknowledgement}

This study was supported by Grant No. 84.128E from Rehabilitation Services Administration of the U.S.A. Department of Education.

\section{RÉSUMÉ}

Les installations qui offrent un 'système' coordiné pour personnes ayant une lésion de la moëlle épinière sont maintenant reconnues préférables aux hôpitaux qui n'offrent qu'un système fragmenté (non-système). Les statistiques des complications de lésions de la moëlle épinière ont été assemblées pendant deux ans pour un 'système' en dehors des Etats-Unis et également pour un 'non-système' dans les Etats-Unis. Ce demier comprenait les soins donnés dans un hôpital local avant l'admission dans l'un des quatorze centres modèles pour lésions de la moëlle épinière.

Toutes complications, particulièrement escarres et infections des reins et de la vessie, ont été observées plus souvent parmi les malades traités aux Etats-Unis.

Les statistiques indiquent que les soins dans une installation coordinée (système) préviennentide coûteuses complications et qu'il est préférable d'envoyer le malade aussitôt que possible dans un centre qui peut répondre à tous ses besoins afin de lui éviter les complications qui ralentissent sa réhabilitation.

\section{ZUSAMMENFASSUNG}

Gegenwärtig sind die Vorteile eines koordinierten 'Pflegesystems' der Rückenmarkverletzten den fragmentarischem Methoden eines 'fehlenden Pflegesystems' als vorziehend anerkannt.

Angaben, welche das Vorkommen von auserwählten Komplikationen bei Patienten mit Ruckenmarkverletzung betreffen, sind für eine Zeitdauer von zwei Jahren zusammengestellt und betreffen ein System ausserhalb der Vereinigten Staaten gelegen und mehrere fehlende Systeme innerhalb den Vereinigten Staaten. Im letzten Falle waren die Patienten in örtlichen Krankenhäusern behandelt vor der Zulassung in einen von den vierzehn existierenden Musterzentrums in den Vereinigten Staaten.

Decubitusgeschwüre and Infektionen des Harnwegesystems waren besonders alle häufigere Komplikationen in der amerikanischen Gruppe den Patienten. Die Angaben deuten an, dass ein Pflegesystem dem fehlendem System vorzuziehen ist infolge der Leistungsfahigkeit im Verhindern der kostbaren Komplikationen.

Je früher der Patient mit Rückenmarkverletzung in ein Rückenmarkzentrum zugelassen wird, wo alle seine Bedürfnisse erfüllt werden können, desto weniger besteht die Wahrscheinichkeit, dass er den Komplikationen, welche das Rehabilitationsbestreben verlangsamen können, ausgesetzt wird.

\section{REFERENCES}

AmERican SPINAL INJURy Association (198I). Guidelines for Facility Categorization and Standards of Care: Spinal Cord Injury. American Spinal Injury Foundation I-20, Chicago.

BEDBROOK, SIR G. (1979). Discerning matters of future importance in paraplegia. Paraplegia, 17, 36-45. 
GuttMann, SIR L. (1976). Spinal Cord Injuries-Comprehensive management and research. Blackwell Scientific Publications, 22-47, Oxford.

Notices IN Federal Register (1979). 44, 3941 $2-4$.

OSTEEN, R. T. \& BARSOMION, E. M. (I98I). Delayed gastric emptying after vagatomy and drainage in the spinal cord injury patient. Paraplegia, 19, 46-9.

Pearman, J. W. \& ENGLAND, E. J. (1973). The urological management of the patient following spinal cord injury. Charles C. Thomas, 46-1 58, Springfield.

Young, J. S., Burns, P. E., Bowen, A. M. \& McCutchen, R. (1982). Spinal Cord Injury Statistics. Good Samaritan Medical Center 130-2, Phoenix. 